some kind of a response. Next month, for example, the University Grants Committee will deliver its promised summary of replies to the questionnaire put out last year to all British universities. Most probably, the committee will be found to have toned down some of the more vigorous defences of established practices by its constituents but to have made up for defaults of this kind by throwing its weight behind the general complaint that the university system is indeed in danger. Thus the committee is unlikely to endorse the extreme demand that academic tenure is inalienable, but will stick up to the best of its ability for the notion that universities should be free to govern themselves. That, at least must be the hope.

Straws in the wind of change are apparent in two other aspects of the relationship between government and the universities finance (which perforce comes from the government in present circumstances) and objectives (where the two parties need to reach an understanding). Since the beginning of the present round of money troubles (in 1981), budgets have been made to shrink further than has been necessary on demographic grounds. No doubt the next forecast of public expenditure will show a cautious retreat from these past privations. But the universities should not set too much store by that. The important need is that the structure of the financial relationship between the two partners should be redesigned.

A study by the Committee of Vice-Chancellors and Principals last month shows the urgent need for change. For British universities collectively, direct subventions by the government accounted for roughly a third of total income in the mid-1930s, but now the proportion has doubled. At the same time, government indirectly pays for roughly a quarter of the cost of running British universities, partly by its payment of university fees and student maintenance grants, partly through the research councils. During this traumatic half century, meanwhile, the total income of British universities from endowments and donations has shrunk from more than 17 per cent to a mere 1 per cent of the total. Put simply, the university system has grown much more quickly than its private sources of support. Now, while some institutions (chiefly Oxford and Cambridge) enjoy an enviable independence from government, most institutions are firmly in its pocket.

The vice-chancellors' committee has some sensible if modest remedies to suggest. British universities have been feckless in failing to draw on the support of their alumni, a well-established practice in the United States, and should mend their ways. And the British Government, which is forever urging the universities to forge closer links with industry, should revise the regulations on the taxation of corporate benefactions so as to ensure that gifts are not a charge on profits after tax but on general income. Most probably the committee, under Dr John Burnett of the University of Edinburgh, goes further than it knows the government will countenance when, with an envious glance at Alberta, it suggests that the government should be prepared to match, pound for pound, what the universities are able to raise from potential benefactors. But the principle that even the government should in the long run benefit if the universities are helped to a greater degree of independence is beyond dispute. The government should promptly say yes.

Two other financial issues are more politically charged. A large part of the reason why the universities are saddled with iniquitous quotas on student numbers is that there is no mechanism by which the cost of student maintenance can be controlled under present law. The committee moves further than any comparable body in recognizing that Britain is unique in its obligation that the cost not merely of students' fees but of their maintenance will be carried by taxation (uniess the parents are well-heeled). Switching to some other system is urgently necessary. The committee flirts with schemes for student loans (which will not save money in the short run), and indeed some reform along these lines should be attempted. But the best course for Britain would be a return to the old system of scholarships for able young people with no artificial restrictions on student numbers. The question whether British universities should be compelled (as now) to charge "economic fees" to students from overseas should be reopened.

What is all this for? The British Government now finds itself in the curious position of being accused of running its universities on too short a shoestring while asking that their contribution to the national economy should be more direct and more valuable. The latest evidence to this effect is a report from the Department of Industry, published at the end of last month, which acknowledges the likely shortage of trained people in the technical fields in which it is especially anxious to succeed - those related to information technology. Mr John Butcher, the minister at the Department of Industry who was chairman of the committee responsible for the study, seems to have been seized with the importance of the objective - so much so that there is once again talk among government officials of organizing a "switch" from arts and humanities to engineering. Again, the next few months should show whether the government will put its money where it mouth is. There is no other way of getting what it wants.

\section{Minds at the helm}

Moves to screen US operators of nuclear power plants smack of pseudoscience.

THE US Nuclear Regulatory Commission (NRC), which professes to be concerned about the mental stability of nuclear power plant employees, is itself behaving rather erratically. It is now proposing regulations that would require "psychological screening" of applicants for jobs that allow "unescorted access" to critical areas of power plants; once on the job such employees would be subject to "continual behavioral observation" by supervisors.

The NRC staff has diligently produced a page of fine print to guide supervisors in this task. The "behavioral changes" they will be looking out for include excessive doodling, lack of a sense of humour, poor eye contact, impatience, borrowing money, yawning, complaining of back pain and playing pranks. (The last point is particularly interesting as, according to the guide, another warning sign of a worker's psychological impurity is that other workers play pranks on him. Apparently everyone is suspect when pranks are involved.).

After detecting these or any of more than 100 other suspicious signs, the supervisor will refer the suspect back to the access authorization office - apparently the same people who administered the "personality test" on him when he applied for the job - for an expert evaluation. There, judgement will be rendered with the assistance of trained professionals, psychiatrists and psychologists who, with scientific precision and dispassion, will determine whether the employee will go mad at the control panel one day.

Unfortunately, many psychiatrists and psychologists (more of the former) seriously believe that they can predict a person's future behaviour. That view has been accepted by more than a few states, which have in the name of science and reason turned over to these professions the authority to order the release of criminals committed to psychiatric institutions following verdicts of not guilty by reason of insanity. Their ability to forecast the behaviour of these subjects is unimpressive. The misplacement of judicial responsibility is enormous. NRC is now asking for comments on its proposal; it is probable that psychiatrists and psychologists will like it if no one else will.

Employers of all sorts, of course - not just nuclear power plant operators - are known to resort to all kinds of strange methods to find the perfectly trustworthy employee; thus the popularity of lie detector tests, handwriting analyses and asking an unsuspecting job applicant to open a window that is nailed shut. None is scientific, all are capricious denials of an employee's reasonable expectation to be judged on his merits and his performance. What NRC is proposing is no more scientific and no less capricious. It will substitute undefined and ultimately pseudoscientific criteria for objective rules of employee conduct and performance; it will elevate a pseudoscientific judgement above the judgement which a supervisor truly can make: the important question is whether the employee doing his job well. 